\title{
MUSLIM AWARENESS IN SCIENCE OF FARAIDH SYSTEMS
}

\author{
Khifni Kafa Rufaida \\ Ngudi Waluyo University \\ khifnikafarufaida@gmail.com
}

\begin{abstract}
Islamic Inheritance Law basically applies to all Muslims in the world. But in fact, a true Muslim society must obey Mawaris jurisprudence is actually more leave even forget this science. Because it is no longer a concern for Muslims, finally arose some disputes between families which is really due to the neglect of science faraidh which has been arranged by God for the benefit of his people. It is important for the writer to contribute how to build awareness of the existence of Muslim faraidh science in the division of inheritance system. In this study, the method used to address the problem is normative. Methods of data collection in this research is done by: Library Researchand Field Research. The analytical methods used this research is qualitative analysis method.

Awareness of the importance of the science of inheritance can be grown in a way memperlajari faraidh science. By studying faraidh will automatically raise awareness faraidh to apply science in the division of the inheritance. The author argues that this faraidh science should be included in a curriculum in Madrasah Diniyyah. The principle of peace is a justifiable manner, so that the atmosphere can be established brotherhood. Throughout the peace was not meant to proscribe lawful or justify the unlawful, then it is allowed. The author thinks that the lack of public knowledge about the law faraidh a major cause of the low awareness of the use of science in the division of islamic inheritance/faraidh.
\end{abstract}

Keywords: Awareness; Faraidh; Muslim.

\section{A. INTRODUCTION}

Life and life is a gift and given pleasure of Allah to mankind. Life is a mandate that will be held responsible by Allah SWT. Islamic Inheritance Law basically applies to all Muslims in the world. So that people can live in accordance with God's will need a guidance in the form of a code of conduct or attitude called Shari'a.

As word of Allah in Surah alJasiyah paragraph 18 provides Shari'a sense that covers all aspects of the Islamic religion. In a general sense synonymous with religion, ${ }^{1}$ whereas in the special Shari'asense include religious law, muamalah and others. ${ }^{2}$ Sharia rule governing the direct relationship between man and man commonly called muamalah this rule covers in which the law of marriage, inheritance and so forth. Inheritance law is one muamalah should receive special attention. Inheritance law is the law governing what should happen to the assets of a person who died, in the sense of the law governing the transfer

1 Mardani 2013, Hukum Islam, P. 10 see Rahmi Hidayati, Dinamika Hukum Islam dalam Lintasan Sejarah, Jakarta: Referensi P. 2

2 Abdul Aziz Dahlan, et al. (Eds), The Encyclopedia of Islam, Vol 6, P. 301 
of wealth left by someone who had died, and the consequences for the heirs. The legal system of inheritance prevailing in Indonesia, among others, customary inheritance law, inheritance law western and Islamic law.

By virtue of the Supreme Court dated May 8, 1991 No. MA / kumdil / 171 / V / K / 1991 determines that the natives Indonesia applicable inheritance law customary for European descent and equivalent and tionghoa applicable inheritance law the west and to the descendants Foreign Orientals (Arabic, Hindu, Pakistan, etc.) applicable laws of the ancestors.

After the promulgation of Islamic Law Compilation Indonesian Presidential Instruction No. 1 of 1991 concerning the issue of inheritance of Indonesia's population is Muslim regulated in Book II Inheritance Law, Article 171 to Article 214 under the supervision of the Religious Courts.

Top sources in formulating Islamic Law Compilation (KHI) is the Qur'an and Al-Hadith. Of course, the problems of inheritance are governed $\mathrm{KHI}$ also refers to already spoken of Allah in the holy book. Allah says in Surah An-Nisa verse 11: God (require) you about the division of inheritance for your children. That is part of a boy equal to 2 (two) daughters. in the next verse "It is the decree of Allah, verily Allah is Knower and Wise." In the Hadith, the Prophet Muhammad SAW said: "Learn faraidh and teach in humans because faraidh is half of the science and be forgotten. Faraidhscience that was first removed from my people. Faraidh science is the study of who is entitled to inheritance and who is not entitled to and also how the size for each heir.
In fact, science is science faraidh largely forgotten by Muslims. A true Muslim society must obey Mawaris jurisprudence is actually more leave even forget this science. Because it is no longer a concern for Muslims, finally arose some disputes between families which is really due to the neglect of science faraidh which has been arranged by God for the benefit of his people.

It is important for the writer to contribute how to build awareness of the existence of Muslim faraidh science in the division of inheritance system.

\section{B. RESEARCH METHODS}

The method is a procedure or a procedure to find something that has a systematic measures. The method is a framework to perform an action, or a framework of thinking constituent ideas, regularity, trending, contextualworthy (relevant) with the intent and purpose. Briefly the method is a system to do because it is a system, then the method is a set of elements that form a unity. ${ }^{3}$ Hadari Nawawi found that a desired goal successfully, it will need a method. The method that is essentially the means used to achieve the goal, then the general purpose of the research is to solve the problem of the measures used should be relevant to the issues formulated. ${ }^{4}$

Research is an activity inquiry conducted under the scientific method, systematically to find a technical and scientific information or new technologies, needs the truth or

3 Husaini Usman and Purnomo Husaini Usman 1995, Metodologi Penelitian Sosial, Jakarta: Bumi Aksara, P. 42

4 Hadari Nawawi 1983, Metode Penelitian Bidang Sosial, Yogyakarta: Gajah Mada University Press, P. 6 
untruth of hypotheses that can be formulated theory or process natural or social phenomenon. ${ }^{5}$ of Understanding methods and research above, it can be concluded that the research method is a method or way to solve a problem that exists, in order to define, locate develop or test the truth of knowledge by collecting, compiling, and interpret words in accordance with guidelines and the rules applicable to a scientific work. ${ }^{6}$

As for the study of law itself is defined as the scientific activities that are based on methods, systematic and specific rationale which aims to study one or several types of symptoms of certain laws by analyzing, but it also held an examination of the legal facts, to then seek a solution to the problems incurred in the relevant legal symptoms. $^{7}$

In preparing this article, the author did some stage in the study as follows:

The method of approach.

Specifications research.

Method of collecting data.

The method of analysis and presentation of data.

In this study, the method used to address the problem is normative meaning in the study adhered to the secondary data consisting of the Qur'an, Hadith, Compilation of Islamic Law and the Law on Religious Courts. Specifications research used is descriptive analytical means to describe the regulations and associated legal theory and practice of positive law concerning the problems,

5 Bambang Wahyu 1991, Penelitian Hukum Dalam Praktek, Jakarta: Sarana Grafika, P.2

6 Ibid, p.3

7 Masri Singarimbun 1983, Metode Penelitian Hukum,Jakarta : LP3S, P. 8. then analyzed and translated to produce a conclusion as an answer to the problems studied.

Methods of data collection in this research is done by: 1) Library Research by studying, analyzing and understanding of the provisions of the Qur' an, Hadith and KHI on Islamic Inheritance Law to determine the level of public awareness in applying Mawaris Islamic law (faraidh). 2) FieldResearch, in this case the author conducted research to see phenomena (facts) within the community. The analytical methods used this study is a qualitative analysis, which means all the data that has been collected is done processing the data of a primary and secondary, so it can be deduced that first made an assessment of the results of processing these data, namely the data analysis process. ${ }^{8}$

\section{DISCUSSION}

\section{Islamic Inheritance Law (Faraidh)}

Islamic Inheritance Law also called faraidh. Faraidh is the plural of the word al-faridhoh which is taken from the word al-fard, ${ }^{9}$ means provisions. Thus, the word faraidh or faridhoh means the provisions of anyone who included heirs entitled to inheritance, the heirs who are not eligible, and how many parts are acceptable to them. ${ }^{10}$

8 Ibid, p. 68.

9 The word Fardh means the provision or administration. View Hussein Amin Nasution, Hukum Kewarisan.. P. 49. Fardu in the Qur'an understanding which contains several provisions (al-Baqarah: 197), liabilities (Surat al-Qasas: 85).

10 Ahmad Rofiq 2012, Fiqh Mawaris, Jakarta: PT. King Grafindo Persada, P. 3 
Faraidh science including science highest danger level, the highest position, the greatest reward, because of the importance of science faraidh, God alone to determine the dose / share. God explained inheritance allotments obtained by each heir, spelled out the numbers in some of the scripture is clear. Why did God until such decisive part, because the property and the division is the source of human greed. That is why God directly set up their own division as well as the details in the verses of the Qur'an, flattening it between the heirs and beneficiaries in accordance with justice that he knew.

In the terminology of science faraidh or Mawaris science is science which deals with matters of transfer of inheritance from a person who has died to the heirs who are still alive, both on the property has been abandoned Yag, who is entitled to receive the inheritance, how many parts each their heirs, as well as how the settlement division of the inheritance. Hasbi Ash-Shiddiqiy Mawaris jurisprudence defines as a study of who gets the inheritance and who does not get the heritage, levels received by each heir and method of apportionment. ${ }^{11}$

In days of yore, the Jahiliyyah, they simply divide the property for adults without children, to men and women did not leave. Damage is increasing because of the Jahiliyyah at the time they allocate to women what is not theirs out of the position, jobs and possessions. Finally, Islam makes provision to do justice to women and glorify it, give the appropriate rights to

11 Hasbi As-Shiddiqiy 2001, Fiqhul Mawaris, Semarang: Rizki Putra Library, P. 8 them as a gift to others. So this was the one faraidh science one of the provisions which respect the existence of women.

The rights associated with existing legacy five (5) to be executed sequentially if all that there are, among others, as follows:

1) Excluded from the estate of deceased settlement needs, such as the shroud and others.

2) The rights associated with abandoned items, such as loans with a guarantee of goods and semisalnya.

3) Repayment debt, whether it is related to God like charity, expiation and so on, or which relate to human beings.

4) Action.

5) Division of inheritance Pillars of Islamic inheritance there are three (3) namely: $A /$ Muwarrits, are deceased; Al-Warits, that he was still alive after the death of Al-Muwarrits; Alhaqqul Mauruts, namely treasures. While the causes of inheritance, among others:

1) Marriage with the correct contract, only with the marriage ceremony husband can get his wife's inheritance and wife could receive rations of her husband.

2) Nasab (Offspring), which is a relative of an upward direction as parents, offspring like a child, to the side like a brother, uncle and their children.

3) Trusts, which ashobah caused merit to his slaves by making it free, then he is entitled to get the inheritance if there is no ashobah of offspring or absence ashab furudh. 
In addition to 3 causes of inheritance, there are also three (3) barrier heir namely:

1) Slavery: A slave could not inherit nor get heir, because he belonged to the master.

2) Killing without foundation: Killer not entitled to inheritance of the people he killed.

3) Religious differences: a Muslim does not inherit the infidels and heathens did not inherit a Muslim.

\section{Muslim Awareness In Science Of FaraidhSystems}

God created in the form of Islamic law demands, as well as instructions to ban to attain a sense of peace, tranquility, and avoid other desrepute. In general, the purpose of the law creator (Syari') in setting its laws are for the benefit and interests and happiness of mankind, whether happiness in mortality (temporary) is, and happiness in the afterlife baqa (eternal) later. ${ }^{12}$ The purpose of Islamic law so it can be captured on the word of Allah in Surah Al-Anbiya verse 107: "and We sent thee but to (become) a mercy to the worlds".

According to Zainuddin Ali, the general purpose of the creation and establishment of the law by God for the benefit, welfare and happiness of mankind, both globally and in Baqa(hereafter). ${ }^{13}$ Including the provisions of Islamic law on the division of inheritance faraidh science

12 Suparman Usman 2001, Hukum Islam, AsasAsas dan Pengantar Studi Hukum Islam in Tata Hukum Indonesia, Jakarta: Gaya Media Pratama, P. 66

13 Zainuddin Ali 2006, Hukum Islam: Pengantar Ilmu Hukum Islam di Indonesia, Jakarta: Sinar Grafika, P. 3 done to create a benefit. Islam provides for the division of inheritance so as to prevent disputes and disputes among his people. This is because the death is often left a deep sorrow because of a dispute between the heirs due to inheritance. To anticipate Islam regulates the division of inheritance in ways that can be used as guidelines. Actually, why Islam requires Muslims to learn and teach science faraidh because the Prophet says that science is the science of inheritance will first be lifted my ummah. As the hadith narrated from Abu Hurairah RA:

$$
\begin{aligned}
& \text { عن الأعرج قال قال رسول الله: يا أبا هريرة } \\
& \text { تعلموالفرائض وعلموها فإنس إنه نصف العلم وإنه } \\
& \text { ينسى وهو أول ما ينزع من أمتى }
\end{aligned}
$$

From A'raj Radhiyallahuanhu that the Messenger of Allah said, "O Abu Hurayrah, learn and teach science faraidh. Because he is half of the science and forgotten. And he was the first to be deprived of my people". (HR. Ibn Majah, Ad-Daruquthuny and Al-Hakim)

By studying and teaching this science should be to maintain the existence of science faraidh. Unfortunately, when many people are studying the Qur'an but not accompanied by enforcing what is commanded in the Qur'an an one provision faraidh science. Faraidh awareness to study is very important because in the opinion of legal scholars faraidh The work that the law is fard kifayah. Fardhu kifayah is if there are some people who do, it can abort some other person. However, if none of the people who carry it out, then all 
Muslims to bear sin, due to neglect of an obligation. ${ }^{14}$

How the division of inheritance according to Islam, this is a must and binding upon every Muslim, whether pious or not pious. If deliberately did not discharge this obligation then clearly a religious offense. Various reasons are the basis for a waiver of this faraidh science. One of them is the goal of harmony, the real reason for this was not grounds to ignore the science. Because nothing is more wise and fair, but that has been set by Allah SWT. If studied faraidh, kifayah, then what is the legal use faraidh science in the division of the Islamic heritage?

Prophet explicitly ordered his followers to carry out the division in accordance with the provisions outlined in the Scriptures of the Qur'an namely in the letter of An-Nisa' Paragraph 7. From the Word of God in Surah An-Nisa, we can conclude that the law to implement and practice the division of inheritance in accordance with the shari'ah at Islam is obligatory (fard ayn) for every Muslim.

Raise awareness for every Muslim to use faraidh the division of inheritance is very important. Why is that? for inheritance by a muslin that is not adapted to faraidh then he is considered to have eaten something that is not a right. As word of Allah in Surah An-Nisa verse 29: O you who believe, do not you eat up the property of others with false. To avoid yourself from this vanity takes possession of a Muslim should be submissive and obedient to the faraidh science in the division of inheritance.

14 Otje Salman S. dan Mustofa Haffas, Hukum Waris Islam, Bandung: PT Refika Aditama, p. 4
Then how to cultivate this awareness before the author discusses how to develop awareness of the importance of science faraidh, the author will explain in advance about the causes of the tendency to ignore science faraidh. First, the normative division of inheritance must be made in accordance with the science faraidh but in reality people will prefer to divide the inheritance with the family. Moreover, the division of kinship has been backed normative rules in the Compilation of Islamic Law, namely Article 183 "heirs may agree to peace in the division of inheritance after each realized parts". But the reality is that the people are not aware of their share in accordance with the shari'ahat Islam. Principle of the family is considered as the principle of the most profitable in the division of inheritance, for example parts of the male: female 2: 1 is not recognized in customary inheritance law. Second, the public assumption that science is only one way faraidh division of inheritance Islam, may also be used or abandoned. Third, the new faraidh Science used as guidelines after their split, in this case the prevention of family breakdown are not heeded. Fourth, in the State of Indonesia procedure division of inheritance in Islam too complicated namely by submitting an application in the Religious Court. As stipulated in Article 49 letter b Law Religious Courts "duty and authority to examine, decide and resolve cases at the first level among people who are Muslims in the areas of: b) inheritance."

In this legacy problem can be reached by two (2) ways, among others:

1. Suit 
In the case of the lawsuit, then in this case there is a dispute about inheritance objects are usually due to an heir who does not want to divide the inheritance, causing conflict among heirs. The end of the lawsuit process will result in a decision.

2. Petition

In the case filed with the Court Religion is a request, then in this condition there is no dispute. The petition against the religious court will issue a legal product called determination. The application process can be submitted to the Religious Court by way of petition signed by the applicant or attorney authorized and directed to the courts that covers the residence Requests (Article 118 HIR / 141 Rbg.)

According to the author the application procedure to the courts that such in setting heirs may trigger the low awareness of Muslims to use Islamic inheritance. Moreover, the length of the judicial process in the religion difficult to ascertain. This is what should be addressed so as not to result in a waiver of the provisions of Allah regarding inheritance. In addition, religious leaders in the community should be a model for surrounding Muslim community to enforce a provision of the Mawarislaw.

Awareness of the importance of the science of inheritance can be grown in a way memperlajari faraidhscience. By studying faraidh will automatically raise awareness faraidh to apply science in the division of the inheritance. But unfortunately, this knowledge will not be touched by the Muslim community who are not educated in boarding schools. For that, the authors found this faraidh science should be included in a curriculum in Madrasah Diniyyah. By incorporating science faraidh in this Madrasah curriculum there will be more Muslims who are studying faraidh early. With the awareness of the importance of science faraidh the breakdown of the family in the division of inheritance can be avoided in such a way.

The birth of Islamic Law Compilation (KHI) has given a new nuance to the inheritance law in Indonesia. Unfortunately, KHI which is actually listed as as a great feat achieved by Muslims, it does not fully require Muslims to obey and comply with the faraidh. For example, there is a provision stating that the heirs may agree or reconcile to determine the division of the inheritance. meaning there is absolutely legally faraidh. This means that in this case there ketidakkonsisntenan forming Act in making the rules of Islamic law which is in accordance with the Qur'an and Hadits. Then how restrictions in using the principle of peace in accordance with Article 183 of Islamic Law Compilation.

Inheritance is such, in fact has been repeatedly made by the Islamic community in Indonesia. These systems allow the Muslim community to choose which way they want in the division of inheritance. Do you think faraidh, customary law system or by other means as agreed. With this provision, it is possible the one of the heirs who will hand over all of his estate to the heirs of the other. For example, boys will be handing over part of his right to his sister. In other words the boy willingly hand over all of his estate was to his sister. This can 
happen when economically tad more affluent than the girl.

Thus the division of inheritance which has become a habit and not create problems among the heirs. This means that these habits have brought maslahah. Habits that cause this maslahah called 'urf. When looking for a legal basis in the Qur' an instigation to terms contained in Surah Al-Hujurat verse 9: "And if there are two classes of those who believe that war be ye reconciled between the two". This verse clearly states, if there was a dispute between two groups of fellow Muslims are required to be reconciled.15

The principle of peace is a justifiable manner, so that the atmosphere can be established pesaudaraan. Throughout the peace was not meant to proscribe lawful or justify the unlawful, then it is allowed. Then the question arises which one takes precedence an obligation (fard ayn) or the common good,author state that provision had been shari'a of God must have been set in a fair and judicious including provisions on the Islamic inheritance. The author has been describe above, that the law is fard kifayahof faraidh study was law observance is fard ayn. Peace principle in Article $183 \mathrm{KHI}$ which incidentally contains good elements indeed their long as it is not intended to proscribe lawful or justify the unlawful, so is the case with the division of inheritance. Do not get us as Muslims ignore fard in with a plea for common benefit. The author argues that whatever the situation is the determination of heirs

15 Baharuddin Ahmad 2015, Eksistensi dan Implementasi Hukum Islam di Indonesia, Yogyakarta: Penerbit Pustaka Pelajar, P. 277278 and determining the amount of the amount of inheritance must be grounded in science faraidh. The element ta'awun in peace principle can also be used without violating the rules of science faraidh.

For example, boys had 2 parts, while girls get one part. Economically tad more affluent, how to apply the elements ta'awun without prejudice to the legal fof araidhis fardhuayn. Boys continue to receive its share is 2 part of the inheritance. After the boy receives his share in accordance with Islamic law, he can give his share with the street Grant. Islam allows for the grant of course that is conducted in accordance with what ruled by Islam.

In anticipation of a violation of the rules of Islamic law, or commonly referred to faraidh hence the need for learning about what and how science faraidh. For the writer considers that the public's knowledge about the law that is still very shallow faraidh is the main cause of the low awareness of the use of science in the division of inheritance faraidhof Islam.

\section{CONCLUSION}

Faraidh science including science highest danger level, the highest position, the greatest reward, because of the importance of science faraidh, God alone to determine the dose / share. God created in the form of Islamic law demands, as well as instructions to ban to attain a sense of peace, tranquility, and avoid ugliness, etc. In Surah Al-Anbiya verse 107: "and We sent thee but to (become) a mercy to the world". Including the provisions of Islamic law on the division of inheritance faraidh science done to create a benefit. Islam provides for the division of inheritance 
so as to prevent disputes and disputes among his people. This is because the death is often left a deep sorrow because of a dispute between the heirs due to inheritance. To anticipate Islam regulates the division of inheritance in ways that can be used as guidelines. Studying faraidhis fardh kifaayat being practiced division of inheritance in accordance with the shari'ah at Islam is obligatory (fard ayn) for every Muslim, then the inheritance by a muslim that is not adapted to faraidh then he is considered to have eaten something that is not a right. Normatively division of inheritance must be made in accordance with the science faraidh but in reality people will prefer to divide the inheritance with the family.

Awareness of the importance of the science of inheritance can be grown in a way memperlajari faraidh science. By studying faraidh will automatically raise awareness faraidh to apply science in the division of the inheritance. But unfortunately, this knowledge will not be touched by the
Muslim community who are not educated in boarding schools. For that, the authors found this faraidh science should be included in a curriculum in Madrasah Diniyyah. By incorporating science faraidh in this Madrasah curriculum there will be more Muslims who are studying faraidh early. With the awareness of the importance of science faraidh the breakdown of the family in the division of inheritance can be avoided in such a way.

The principle of peace is a justifiable manner, so that the atmosphere of brotherhood can be established. Throughout the peace was not meant to proscribe lawful or justify the unlawful, then it is allowed. In anticipation of a violation of the rules of Islamic law, or commonly referred to faraidh hence the need for learning about what and how science faraidh. For the writer considers that the public's knowledge about the law that is still very shallow faraidh is the main cause of the low awareness of the use of science in the division of inheritance faraidhof Islam. 


\section{BIBLIOGRAPHY}

\section{Books:}

Al-Qur'an

Al-Hadist

Abdul Aziz Dahlan, dkk. (eds), Ensiklopedia Islam, Jilid 7, Jakarta: PT Ichtiar Baru van Hoeve, 2005.

Ahmad Rofiq, Fiqh Mawaris, Jakarta: PT. Raja Grafindo Persada, 2012.

Baharuddin Ahmad, Eksistensi dan Implementasi Hukum Islam di Indonesia, Yogyakarta:

Penerbit Pustaka Pelajar, 2015.

Bambang Wahyu, Penelitian Hukum Dalam Praktek, Jakarta : Sarana Grafika, 1991.

Hasbi As-Shiddiqiy, Fiqhul Mawaris, Semarang: Pustaka Rizki Putra, 2001.

Hadari Nawawi, Metode Penelitian Bidang Sosial, Yogyakarta: Gajah Mada University Press, 1983.

Husaini Usman dan Purnomo Husaini Usman, Metodologi Penelitian Sosial, Jakarta: Bumi Aksara, 1995.

Rahmi Hidayati, Dinamika Hukum Islam dalam Lintasan Sejarah, Jakarta: Referensi, 2013.

Masri Singarimbun, Metode Penelitian Hukum,Jakarta : LP3S, 1983.

Suparman Usman, Hukum Islam, Asas-Asas dan Pengantar Studi Hukum Islam dalam Tata Hukum Indonesia, Jakarta: Gaya Media Pratama, 2001.

Otje Salman S. dan Mustofa Haffas, Hukum Waris Islam, Bandung: PT Refika Aditama.

Zainuddin Ali, Hukum Islam: Pengantar IImu Hukum Islam di Indonesia, Jakarta: Sinar Grafika, 2006. 